\title{
ПРОЕКТИРОВАНИЕ ПРОГРАММЫ ПСИХОЛОГО- ПЕДАГОГИЧЕСКОГО СОПРОВОЖДЕНИЯ ОБУЧАЮЩИХСЯ С ОГРАНИЧЕННЫМИ ВОЗМОЖНОСТЯМИ ЗДОРОВЬЯ 1
}

\section{DESIGNING A PROGRAM \\ OF PSYCHOLOGICAL AND PEDAGOGICAL SUPPORT FOR STUDENTS WITH DISABILITIES \\ S. Inevatkina V. Vlasova D. Konovalova}

Summary: The article substantiates the need to design a program of psychological and pedagogical support for students with disabilities. The features of the development of primary schoolchildren with speech impairments and mental retardation are considered. The concepts of «design» and "psychological and pedagogical support» are considered. The features of the proposed program are described.

Keywords: design, psychological and pedagogical support, junior schoolchildren, students with speech disorders, students with mental retardation.

\author{
Иневаткина Светлана Евгеньевна \\ K.псх.н., дочент, Мордовский государственный \\ педагогический университет им. М.Е. Евсевьева \\ (2. Саранск) \\ svetlaj23@mail.ru \\ Власова Виктория Ивановна \\ Мордовский государственный педагогический \\ университет им. М.Е. Евсевьева (г. Саранск) \\ Коновалова Дарья Владимировна \\ Мордовский государственный педагогический \\ университет им. М.Е. Евсевьева (2. Саранск)
}

Аннотация: В статье обосновывается необходимость проектирования программы психолого-педагогического сопровождения обучающихся с ограниченными возможностями здоровья. Рассматриваются особенности развития младших школьников с нарушениями речи и с задержкой психического развития. Рассматриваются понятия «проектирование» и «психолого-педагогическое сопровождение». Описываются особенности предложенной программы.

Ключевые слова: проектирование, психолого-педагогическое сопровождение, младшие школьники, обучающиеся с нарушениями речи, обучающиеся с задержкой психического развития.

характеризуется недопониманием смысловых оттенков слов, их переносного смысла. Обучающиеся не используют в речи синонимы, антонимы, затрудняются при использовании многозначных слов. Такая речь маловыразительная и не позволяет передавать говорящему свою мысль в полном объеме. Нарушения грамматики способствуют тому, что обучающийся может неправильно употреблять род, число существительного, затрудняется в согласовании существительного с прилагательными и числительными. Также встречаются трудности в образовании множественного числа, при употреблении предлогов.

Наличие задержки психического развития характеризуется нарушением скорости психических процессов, что приводит к временному несоответствию с возрастными показателями. При указанном нарушении фиксируется сниженный объем памяти, непроизвольное внимание, нарушения ее концентрации и распределения, инертность мышления, нарушения работоспособности, речи, а также способствует появлению значительного количества ошибок при письме. Нарушение лексики

Исследование выполнено в рамках сетевого гранта ФГБОУ ВО Мордовского государственного педагогического института им. М. Е. Евсевьева и ФГБОУ ВО «Чувашский государственный педагогический университет им. И. Я. Яковлева» по теме «Психолого-педагогическое сопровождение лиц с ограниченными возможностями здоровья». 
низкая мотивация. Также часто задержку психического развития сопровождают нарушения в поведении: обучающиеся данной категории испытываю значительные трудности при соблюдении дисциплины.

С одной стороны, представленные особенности развития обучающихся с нарушениями речи и с задержкой психического развития свидетельствуют о наличии значительных трудностей в развитии младших школьников, с другой стороны, проанализированные особенности задают ориентир для коррекции, так как Федеральный государственный образовательный стандарт начального общего образования для младших школьников с указанными нарушениями подразумевает цензовое образование, сопоставимое по уровню с образованием сверстников.

Для достижения указанных ориентиров необходимо проектирование программы психолого-педагогического сопровождения обучающихся с ограниченными возможностями здоровья для преодоления возможных трудностей в процессе обучения.

Анализ теоретических работ отечественных исследователей (В.П. Бедерхановой, П.Б. Бондарева, В.Е. Курочкиной, Л.А. Филимонюк) позволяет определить проектную деятельность как процесс моделирования и реализации ряда спланированных последовательных действий, которые позволяют эффективно достигнуть запланированный результат $[1 ; 3 ; 6]$.

Педагогическое проектирование подразумевает планирование, нацеленное на решение актуальных образовательных задач и реальное практическое преобразование сложившейся образовательной ситуации за определенный период времени.

В свою очередь, психолого-педагогическое сопровождение является педагогически управляемой деятельностью с цикличной структурой, состоящей из четырех этапов: диагностического, поисково-вариативного, практико-действенного и аналитического. Изучение работ В.Н. Богдановой, Г.Ф. Даниловской, Е.С. Семкиной, Е.И. Казаковой позволяет утверждать о том, что основной целью сопровождения является непрерывная поддержка обучающихся с ограниченными возможностями здоровья силами всех специалистов $[2 ; 4 ; 5]$.

В формате данной работы будет рассмотрен вопрос проектирования программы психолого-педагогического сопровождения младших школьников с нарушениями речи и задержкой психического развития.

Опытно-экспериментальная работа была реализована на базе образовательных организаций г. Саранска. В эксперименте приняли участие 11 младших школьни- ков с нарушениями речи и 11 младших школьников с задержкой психического развития. В первую очередь, были изучены особенности познавательного и речевого развития обучающихся указанных категорий. С этой целью использовались методики: «Обобщение», «Исключение лишнего», «Парные аналогии», «Назови и посчитай звуки», «Повтори за мной», «Сюжетная картина».

Анализ результатов позволяет утверждать, что у большей части испытуемых с задержкой психического развития $(72,7 \%)$ способности обобщать, умения находить общее в предметах и явлениях, умения выражать найденное общее в виде конкретного понятия сформированы на уровне ниже среднего. При выполнении заданий испытуемым требовалась постоянная помощь экспериментатора. В свою очередь, младшие школьники с нарушениями речи (81,8 \%) продемонстрировали средний уровень исследуемых умений. Задания выполняли правильно, но возникали сложности при вербальном объяснении.

Также был исследован уровень сформированности способности к классификации и анализу. Большая часть испытуемых с задержкой психического развития $(81,8$ \%) показали уровень ниже среднего, а в группе младших школьников с нарушениями речи в основном (72,7 \%) продемонстрировали средний уровень способности к классификации и анализу. Аналогичные результаты оказались и при исследовании уровня сформированности умения определять логические связи между понятиями; умения устойчиво сохранять заданный способ рассуждений при решении ряда разнообразных задач: большая часть испытуемых с задержкой психического развития $(81,8 \%)$ продемонстрировали уровень ниже среднего, в то время как (72,7 \%) младших школьников с нарушениями речи показали средний уровень сформированности указанных умений.

Далее были проанализированы результаты исследования речевого развития. Оказалось, что у большинства младших школьников с нарушениями речи $(72,7 \%)$ и с задержкой психического развития (81,8 \%) речевое развитие ниже среднего уровня. Испытуемые допускали ошибки при выделении позиции звука в слове, испытывали достаточные трудности в правильности и точности воспроизведения предложений, состоящих из слов сложной слоговой структуры, демонстрировали большие сложности в воспроизведении слов сложной слоговой структуры, испытывали трудности в дифференциации согласных и гласных звуков в слове, резко нарушена связность речи. При выполнении заданий часто требовалась помощь экспериментатора.

Таким образом, у большей части младших школьников с нарушениями речи средний уровень познавательного развития и сниженный уровень речевого развития. 
В свою очередь, у большинства младших школьников с задержкой психического развития сниженный уровень как познавательного, так и речевого развития.

С учетом полученных результатов была спроектирована программа психолого-педагогического сопровождения младших школьников с нарушениями речи и с задержкой психического развития. Данная программа предусматривает создание специальных условий обучения младших школьников указанных категорий с учетом их особых образовательных потребностей. Программа направлена на создание системы комплексной помощи обучающимся с ограниченными возможностями здоровья в освоении основной образовательной программы, коррекцию недостатков в развитии обучающихся, их социальную адаптацию.

Основные направления, реализуемые в рамках указанной программы: устранение несоответствий уровня психического развития ребенка возрастной норме; повышение познавательной и учебной мотивации; разрешение коммуникативных проблем; устранение эмоциональных нарушений поведения; повышение успеваемости по основным предметам.

При работе с младшими школьниками подбор методов и приемов осуществлялся с учетом особенностей развития. Так, блок для обучающихся с нарушениями речи предполагает использование в работе схем, памяток для наилучшего усвоения правил, вербальных прие- мов для расширения лексического запаса речи. Предлагается перефразирование содержания словосочетаний, другими словами, подбор определений к родовому понятию; создание наглядных или словесных ситуаций, побуждающих обучающихся к высказываниям.

Для обучающихся с задержкой психического развития необходим подбор заданий, максимально возбуждающих активность ребенка, пробуждающих у него потребность в познавательной деятельности, требующих разнообразной деятельности. Для наилучшего запоминания необходимо повторное объяснение учебного материала и подбор дополнительных заданий. Обязательно постоянное использование наглядности, наводящих вопросов, аналогий, использование многократных указаний, упражнений, использование заданий с опорой на образцы, доступных инструкций. Также возможно использование карточек, схем с разбором и примерами решения задач для образца.

Результаты, полученные в ходе изучения динамики развития младших школьников с ограниченными возможностями здоровья, показали эффективность спроектированной программы, так как среди младших школьников с нарушениями речи большая часть испытуемых продемонстрировали высокий уровень сформированности познавательного и речевого развития, а среди младших школьников с задержкой психического развития - средний уровень.

\section{ЛИТЕРАТУРА}

1. Бедерханова, В.П. Педагогическое проектирование в инновационной деятельности: учебн. пособие / В.П. Бедерханова, П.Б. Бондарев. - Краснодар: ККИДППО, 2000. -54 c.

2. Богданова, В.Н. Психолого-педагогическое сопровождение детей с задержкой психического развития специалистами центра психолого-медико-социального сопровождения / В.Н. Богданова // Известия Российского государственного педагогического университета им. А.И. Герцена. - 2004. -№ 41. - С. 5-13.

3. Бондарев, П.Б., Курочкина В.Е. Проектная деятельность учителя : учебное пособие / П.Б. Бондарев, Курочкина В.Е. ; под ред. П.Б. Бондарева - Краснодар, 2002. -44 c.

4. Гамаюнова, А.Н. Программа коррекционной работы как основа реализации особых образовательных потребностей обучающихся с ограниченными возможностями здоровья в инклюзивном образовании / А.Н. Гамаюнова, А.Ш. Биксалиева // European Social Science Journal (Европейский журнал социальных наук). - 2018. - № 7(2). - С. 239-250.

5. Даниловская, Г.Ф. 0 психолого-педагогическом сопровождении детей с ограниченными возможностями здоровья в условиях дошкольного инклюзивного центра / Г.Ф. Даниловская, Е.С. Семкина // Педагогика, психология и технологии инклюзивного образования: материалы III международной научнопрактической конференции. - Казань: Познание, 2015. - С. 414-417.

6. Казакова, Е.И. Процесс психолого-педагогического сопровождения / Е.И. Казакова // На путях к новой школе. - 2009. - № 1. - С. $36-46$.

7. Минаева, Н.Г. Формирование готовности родителей детей с ограниченными возможностями здоровья к решению проблем их образования / Н.Г. Минаева // Гуманитарные науки и образование. - 2014. - № 1 (17). - С. 57-61.

8. Рябова, Н.В. Мониторинг уровня сформированности универсальных учебных действий младших школьников / Н.В. Рябова, Е.А. Демидова, О.В. Терлецкая 0.В. // Гуманитарные науки и образование. - 2018. - Том 9. - № 3. - С. 113- 119.

9. Филимонюк, Л.А. Педагогическое проектирование как индивидуальная и коллективная деятельность / Л.А. Филимонюк // Известия высших учебных заведений. Северо-Кавказский регион. Серия: Общественные науки. - 2017. - № 2. - С. 114-118. 